\title{
BUDAYA ETIK AKUNTABILITY PERAWAT DALAM PEMODELAN PATIENT SAFETY DI RUMAH SAKIT
}

\author{
Emyranda Samosir \\ emyrandasamosir@gmail.com
}

\begin{abstract}
Keselamatan pasien dan kualitas pasien adalah jantung dari penyampaian layanan kesehatan. Untuk setiap pasien, yang merawat, anggota keluarga dan profesional kesehatan, keselamatan sangat penting untuk penegakan diagnosa, tindakan kesehatan dan perawatan. Dokter, perawat dan semua orang yang bekerja di sistem kesehatan berkomitmen untuk merawat, membantu, menghibur dan merawat pasien dan memiliki keunggulan dalam penyediaan layanan kesehatan untuk semua orang yang membutuhkannya. Telah ada investigasi yang signifikan dalam beberapa tahun terakhir dalam peningkatan layanan, peningkatan kapasitas sistem, perekrutan profesional yang sangat terlatih dan penyediaan teknologi dan perawatan baru. Namun sistem kesehatan di seluruh dunia, menghadapi tantangan dalam menangani praktik yang tidak aman, profesional layanan kesehatan yang tidak kompeten, tata pemerintahan yang buruk dalam pemberian layanan kesehatan, kesalahan dalam diagnosis dan perawatan dan ketidakpatuhan terhadap standar (Commission on Patient Safety \& Quality Assurance, 2008. Permasalahan etik didunia rumah sakit seperti halnya fenomena gunung es. Di Indonesia banyak permasalahan yang tidak terungkap. Mulai dari kasus dugaan malpraktik, kelalaian dalam penanganan pasien, diskriminasi terhadap pasien, sampai tindak criminal lainnya. Tenaga medis memiliki peran penting dalam menciptakan pelayanan kesehatan yang ermutu. Di antaranya dalam menerapkan budaya keselamatan pasien. Saat ini keselamatan pasien belum sepenuhnya menjadi budaya dalam pelayanan kesehatan. Hal ini terlihat dari masih adanya kasus seperti malpraktik, diskriminasi, dan lainnya.
\end{abstract}

Kata Kunci : Kode Etik,Akuntabilitas,Budaya Keselamatan Pasien, 


\section{Latar Belakang}

Rumah sakit adalah sarana pelayanan kesehatan yang dibutuhkan ketika seseorang sakit dan membutuhkan bantuan dengan tujuan untuk menyelamatkan kondisi pasien. Perawat sebagai salah satu tenaga kesehatan yang mempunyai jumlah cukup dominan di rumah sakit yaitu sebesar 50 sampai $60 \%$ dari jumlah tenaga kesehatan yang ada. Pelayanan asuhan keperawatan yang diberikan kepada pasien merupakan pelayanan yang terintegrasi dari pelayanan kesehatan yang lainnya dan memiliki peran yang cukup penting bagi terwujudnya kesehatan dan keselamatan pasien. Perawat adalah pejabat eksekutif kesehatan dengan waktu kerja tertinggi yang memberikan 24 jam pelayanan terus menerus serta harus berkolaborasi dengan tim kesehatan lain dan oleh karena itu dapat menyebabkan atau berisiko terjadinya Insiden Keselamatan Pasien. Selain itu, perawat memiliki peran yang paling dominan dalam mencegah terjadinya kesalahan dalam pengobatan, termasuk pelaporan insiden, mendidik diri sendiri dan orang lain.

Keselamatan pasien adalah prinsip dasar dalam pelayanan kesehatan. Menurut Depkes RI (2008) Keselamatan pasien (patient safety) rumah sakit adalah suatu asuhan pasien lebih aman. Sistem tersebut meliputi: assessmen risiko, identifikasi dan pengelolaan hal yang berhubungan dengan risiko pasien, pelaporan dan analisis insiden, kemampuan belajar dari insiden dan tindaklanjutnya serta implementasi solusi untuk meminimalkan timbulnya risiko. Sistem tersebut diharapkan dapat mencegah terjadinya cedera yang disebabkan oleh kesalahan akibat melaksanakan suatu Tindakan atau tidak melakukan tindakan yang seharusnya dilakukan. Kurangnya kemanan dan sistem yang baik merupakan masalah yang dihadapi oleh penyedia pelayanan kesehatan untuk menyeberangi jurang dari perawatan yang bisa diberikan saat ini untuk mencapai perawatan yang seharusnya diberikan (IOM,2000). Perawat memiliki tanggungjawab dalam setiap tindakan yang dilakukannya. Akuntabilitas(Tanggung jawab) merupakan standar yang pasti bahwa tindakan seorang professional dapat dinilai dalam situasi yang tidak jelas atau tanpa terkecuali.

\section{Tujuan}

Tujuan dari keselamatan pasien ialah :

1. Terciptanya budaya keselamatan pasien di rumah sakit

2. Meningkatnya Akuntabilitas rumah sakit terhadap pasien

3. Menurunnya KTD di Rumah Sakit 
4. Terlaksananya program-program pencegahan sehingga tidak terjadi penggulangan KTD

\section{Metode}

Rancangan penugasan kajian ini menggunakan literature review berdasarkan buku teks, buku referensi, jurnal, e-book (yang dipublikasikan 10 tahun terakhir) dan menggunakan dua belas sumber referensi dengan menganalisis, eksplorasi, dan kajian bebas sesuai dengan judul penugasan kajian ini

\section{Hasil}

Keselamatan pasien adalah prinsip dasar dalam pelayanan kesehatan. Menurut Depkes RI (2008) Keselamatan pasien (patient safety) rumah sakit adalah suatu sistem dimana rumah sakit membuat asuhan pasien lebih aman. Sistem tersebut meliputi: assessmen risiko, identifikasi dan pengelolaan hal yang berhubungan dengan risiko pasien, pelaporan dan analisis insiden, kemampuan belajar dari insiden dan tindaklanjutnya serta implementasi solusi untuk meminimalkan timbulnya risiko. Sistem tersebut diharapkan dapat mencegah terjadinya cedera yang disebabkan oleh kesalahan akibat melaksanakan suatu Tindakan atau tidak melakukan tindakan yang seharusnya

dilakukan.Terdapat 3 fase dalam sitematika langkah penerapan Keselamatan
Pasien Rumah Sakit (KPRS) yaitu : persiapan,pelaksana,dan evaluasi .

Kunci pencegahan cedera dalam pelayanan keperawatan adalah identifikasi risiko. Hal ini sangat tergantung pada budaya kepercayaan, kejujuran, integritas, dan keterbukaan berkomunikasi dalam sistem asuhan keperawatan.Tanggung jawab diperlukan untuk memenuhi kebutuhan dan kinerja yang ditampilkan guna memperoleh hasil pelayanan keperawatan atau kebidanan yang berkualitas tinggi.

\section{Pembahasan}

Malpraktik dan keselamatan pasien tidak lepas dari kode etik yang dijalankan oleh tenaga medis tersebut, seperti perawat. Profesionalisme keperawatan menjadi kontrak sosial antara profesi keperawatan dengan masyarakat. Masyarakat telah memberikan kepercayaan kepada perawat, sehingga perawat harus menlaksanakan tugasnya dengan memberikan standar kompetensi yang tinggi dan tanggung jawab moral yang baik. Perawat memiliki tanggung jawab terhadap keselamatan dan keamanan pasien selama berada di rumah sakit. Perawat membutuhkan aturan hukum yang lebih tinggi yang dapat mengatur kualitas dan pelayanan, termasuk juga sanksi bagi perawat yang tidak melaksanakan tugasnya dengan baik. Perawat dalam 
menjalankan tugasnya harus sesuai dengan kode etik dan Standar Operasicnal Prosedur (SOP) yang telah ditetapkan.

Tanggung jawab menunjukkan kewajiban. Ini mengarah kepada kewajiban yang harus dilakukan untuk menyelesaikan pekerjaan secara professional. Manajer dan para staf harus memahami dengan jelas tentang fungsi tugas yang menjadi tanggung jawab masing-masing perawat dan bidan serta hasil yang ingin dicapai dan bagaimana mengukur kualitas kinerja stafnya. Perawat yang professional akan bertanggung jawab atas semua bentuk tindakan klinis keperawatan atau kebidanan yang dilakukan dalam lingkup tugasnya.

Teori Reason menyatakan bahwa insiden keselamatan pasien disebabkan oleh dua faktor, kesalahan laten dan kesalahan aktif. Kesalahan laten terkait dengan insiden keselamatan pasien meliputi lingkungan eksternal, manajemen, lingkungan sosial atau organisasi, lingkungan fisik, interaksi antara manusia dan sistem. Budaya keselamatan adalah bagian dari kesalahan laten yang terkait dengan manajemen, sedangkan indikator budaya keselamatan meliputi kerja sama, komunikasi, kepemimpinan, pelaporan dan respon terhadap kesalahan tidak menghukum. Kunci pencegahan cedera dalam pelayanan keperawatan adalah identifikasi risiko. Hal ini sangat tergantung pada budaya kepercayaan, kejujuran, integritas, dan keterbukaan berkomunikasi dalam sistem asuhan keperawatan.

Tanggung jawab diperlukan untuk memenuhi kebutuhan dan kinerja yang ditampilkan guna memperoleh hasil pelayanan keperawatan atau kebidanan yang berkualitas tinggi. Yang perlu diperhatikan dari pelaksanaan tanggung jawab adalah memahami secara jelas tentang "uraian tugas dan spesifikasinya" serta dapat dicapai berdasarkan standar yang berlaku atau yang disepakati. Hal ini berarti perawat mempunyai tanggung jawab yang dilandasi oleh komitmen, dimana mereka harus bekerja sesuai fungsi tugas yang dibebankan kepadanya.

Mulai tahun 2007, WHO Collaborating Center For Patient Safety berupaya menetapkan Sembilan Solusi keselamatan pasien untuk mempermudah pendeteksian terjadinya masalah pada keselamatan pasien di Rumah Sakit, yaitu : (1) Perhatikan nama obat, rupa dan ucapan mirip (look-alike, sound-alike medication names). (2) Pastikan Identifikasi pasien, (3) Komunikasi secara benar saat serah terima pasien, (4) Pastikan tindakan yang benar pada sisi tubuh yang benar, (5) Kendalikan cairan elektrolit pekat, (6) Pastikan akurasi pemberian obat pada pengalihan pelayanan, (7) Hindari salah cateter dan salah sambung gelamng, (8) Gunakan alat injeksi sekali pakai, dan (9) 
Tingkatkan kebersihan tangan unuk pencegahan infeksi nosokomial (WHO, 2007 dalam Tim KP-RS RSUP Sanglah Denpasar, 2011). KKP-RS dalam Panduan Nasional keselamatan Pasien Rumah sakit membuat sitematika langkah penerapan Keselamatan Pasien Rumah Sakit (KPRS) yang terdiri dari 3 fase yaitu: fase persiapan, fasepelaksanaan dan faseevaluasi.

1. Fase Persiapan :

Menetapkan kebijakan, rencana jangka pendek dan program tahunan keselamatan pasien rumah sakit.

2. Fase Pelaksanaan

Deklarasi gerakan Keselamatan pasien,program 7 langkah keselamatan pasien,penerapan standar akreditasi keselamatan pasien, buat unit sebagai model (pilot project), buat programprogram kusus terkait keselamatan pasien seperti,program cuci tangan, dokter penanggung jawab pasien, pelaporan dan sebagainya, bentuk forum diskusi periodikuntuk pengembanganKPRS.

\section{Fase Evaluasi}

Evaluasi menyeluruh setahun sekali untuk memperbaikiprogram KPRS.

Mengacu pada hal tersebut, maka

RS harus merancang proses baru atau memperbaiki proses yang ada, memonitor dan mengevaluasi kinerja melalui pengumpulan data, menganalisis secara intensif KTD dan melakukan perubahan untuk meningkatkan kinerja serta keselamatan pasien. Proses perancangan tersebut harus mengacu pada visi, misi dan tujuan RS, kebutuhan pasien, petugas pelayanan kesehatan, kaidah klinis terkini, praktik bisnis yang sehat dan faktor-faktor lain yang berpotensi risiko bagi pasien sesuai dengan "Tujuh Langkah Keselamatan Pasien Rumah Sakit”, yaitu: (DepkesRI, 2008).

- Bangun kesadaran akan nilai Keselamatan Pasien Ciptakan kepemimpinan dan budaya yang terbuka dan adil

- Pimpin dan dukung staf anda Bangunlah komitmen dan fokus yang kuat dan jelas tentang keselamatan Pasien di rumah sakit.

- Integrasikan aktivitas pengelolaan risiko.Kembangkan sistem dan proses pengelolaan risiko, serta lakukan identifikasi dan assesmen hal yang potesial bermasalah

- Kembangkan sistem pelaporan.Pastikan staf anda agar dengan mudah dapat melaporkan kejadian/insiden, serta rumah sakit mengatur pelaporan kepada Komite Keselamatan Pasein Rumah Sakit (KKPRS)

- Libatkan dan berkomunikasi cara komunikasi yang terbuka dengan pasien

- Belajar dan berbagi pengalaman tentang Keselamatan Pasien 
- Cegah cedera melalui implementasi sistem Keselamatan Terdapat 3 pilar utama untuk mencapai target budaya keselamatan yang generatif. Pertama, Proactive Invention, pada pilar ini, individu akan selalu proaktif dalam mengintervensi praktik-praktik yang dipandang mengabaikan faktor keselamatan. Tujuannya adalah untuk mempertahankan tingkat kecelakaan yang terjadi sangat minimal atau bahkan sampai pada titik nol. Kedua, Individual Qonsequences, yaitu individu harus menyadari bahwa setiap tingkah lakunya akan menghasilkan konsekuensi keselamatan bagi dirinya dan bagi orang lain. Oleh karena itu, prediksi-prediksi mengenai resiko bagi keselamatan sampai hal yang sekecil-kecilnya selalu harus dilakukan sebelum melakukan tindakan tertentu. Ketiga, Personal Responsibilities, pilar ketiga ini mengacu pada prinsip bahwa setiap individu mempunyai tanggung jawabnya masing-masing. Tanggung jawab ini harus dipegang dan dilaksanakan selalu.

\section{Penutup}

Patient Safety atau keselamatan pasien merupakan isu global yang mempengaruhi negara-negara di semua tingkat pembangunan. Meskipun perkiraan ukuran permasalahan masih belum pasti, khususnya di negara berkembang dan negara transisi/konflik, ada kemungkinan bahwa jutaan pasien seluruh dunia menderita cacat, cedera atau meninggal setiap tahun karena pelayanan kesehatan yang tidak aman. Mengurangi kejadian yang membahayakan bagi pasien merupakan masalah dalam pelayanan kesehatan bagi setiap orang, dan terdapat banyak hal yang harus dipelajari dan dibagi antara negara-negara maju dengan negara-negara berkembang dan negara dalam transisi/konflik tentang masalah keselamatan pasien (World Health Organization, 2009). WHO juga mengingatkan bahwa "keselamatan pasien tidak hanya tentang data statistik tetapi melibatkan kerusakan yang nyata pada kehidupan orang-orang". Oleh karenanya semua strategi dan program keselamatan pasien harus menjadi prioritas dalam pelayanan kesehatan. Pasien, professional kesehatan dan pembuat kebijakan semua harus bekerja sama untuk membangun sistem kesehatan yang lebih aman.

Dalam mewujudkan keselamatan pasien diperlukan kesadaran diri perawat akan penerapan kode etik keperawatan dalam melakukan asuhan keperawatan guna memkasimalakan pelayanan Kesehatan.Salah satu kode etik yang dimaksud ialah akuntabilitas perawat.Seorang perawat harus menerapkan akuntabilitasnya dalam melakukan asuhan keperawatan .Akuntabilitas ini sangat ditekankan untuk diimplemenbtasikan dalam 3 fase dalam 
Langkah penerapan keselamatan pasien.Dengan sadaranya perawat akan konsep akuntabilitas dalam asuhan keperawatannya dapat memperkecil potensi kecelakan pasien.

\section{Daftar Pustaka}

Herawati,Y.T (2015).

Budaya Keselamatan Pasien Di

Ruang Rawat Inap Rumah Sakit X

Kabupaten Jember.Jurnal IKESMA .11(1).53-54.

Kamil,H.(2017).

PATIENT SAFETY. Idea Nursing

Journal Hajjul Kamil.1(1).4-7

Kementrian Kesehatan RI. (2015).

Situasi Kesehatan Kerja

InfoDATIN: Pusat Data dan

Informasi Kementrian Kesehatan

$R I$.

Mudayana,A.A.(2014).

Peran Aspek Etika Tenaga Medis

Dalam Penerapan Budaya

Keselamatan Pasien Di Rumah

Sakit. Jurnal Kedokteran

Andalas.37(1).77.

Najihah.(2018).

Budaya Keselamatan Pasien Dan

Insiden Keselamatan Pasien
Di Rumah Sakit: Literature Review.Jurnal Of Islamic Nursing.3(1).2-5

Nazirah,R.\&Yuswardi.(2017).

Perilaku Perawat Dalam

Penerapan Manajemen Kesehatan

Dan Keselamatan Kerja (K3) Di

Aceh.Idea Nursing Journal.3(3).9-

12

Permadhi, A. (2013).

Hubungan Budaya

Keselamatan Pasien Dalam

Pelayanan Keperawatan dan

Insiden Keselamatan Pasien di

Instalasi Rawat Inap RSD $d r$.

Soebandi Jember. Retrieved 11 23,

2015, from

http://repository.unej.ac.id/bitstream/ha

ndle/123456789/56073/AGUNG\%2OPE

RMADHI_1.pdf? sequence $=1$

Simamora, R. H. (2018).

Buku ajar keselamatan pasien melalui timbang terima pasien berbasis komunikasi efektif: SBAR. Medan: USUpress.

Simamora, R. H. (2020).

Learning of Patient Identification in Patient Safety Programs Through Clinical Preceptor 
Update, 20(3), 553-556.

Tukatman.,Sulistiawati.et.al.(2015).

Analisis Keselamatan Dan

Kesehatan Kerja Perawat Dalam

Penanganan Pasien Di Rumah

Sakit Benyamin Guluh Kabupaten

Kolaka. Jurnal Ners 10(2).66-68

Utarini, A. (2012).

Keselamatan Pasien dan Mutu

Pelayanan Kesehatan : Menuju

Kemana? Jurnal Managemen

Pelayanan Kesehatan Volume 15

No. 04 Desember 2012, 159-160.

Yasmi,Y.\& Hasbullah.(2015).

Faktor-Faktor Yang Berhubungan

Dengan Budaya Keselamatan

Pasien Di Rumah Sakit Karya

Bhakti Pratiwi Bogor Tahun

2015.Jurnal ARSI.4(2).98-101. 